\title{
The Counter Secularization
}

Secularism (and atheism) are the latest "isms" promoting anti-transcendental, and therefore, evil, acts. Secularization is a distortion of freedom; it is anti-planet and therefore pollution and it is anti-Catholic for sure. It is time to counterattack with the Ten Commandments:

I. There is a God. Secularists/atheists are liars and materialistic spiritless nihilists. They hide behind "science" by misusing it.

II. Seek the truth and do not use or believe words in vain by being suggestible or gullible to the contemporary press and media which do nothing but sell "influence" more than give full information. Do not be gullible to anti-transcendental thoughts or suggestible to antitranscendental acts.

III. Keep the Sabbath -- go to Mass -- Leave the earth and take time out to be uplifted and participate in the Statimuum. Get off the world by the Sabbath -- a spirit filled day ignoring the craziness of secularists and atheists.

IV. Respect and promote the traditional family. Do nothing which jeopardizes this unity of man and woman to continue the species and to praise God.

V. Do not kill, but respect life and all its forms consistent with the hierarchy of life recognizing that man is an order of magnitude higher than the other animals. Abortion, euthanasia are to be rejected.

VI. Extramarital sex is nothing but trouble. Natural law rules. Do not adore the squirt/moan - slime/squeal reflex distortion of human sexuality in the animal kingdom. Genuine planetary sexual activity is for making babies after you are married.

VII. Create, produce, maintain, develop and respect private property for yourself and all others.

VIII. Truth and oneness are universal goals for all human actions.

IX. Maintain human sexuality for reproduction/unition in marriage. Make all your relationships trustworthy, honorable and holy.

X. Use all matter for good and beauty.

Volume 5 Issue 2 - 2016
Dr. Samuel A Nigro M.D*
Retired, Assistant Clinical Professor Psychiatry, Case Western
Reserve University School of Medicine, USA
*Corresponding author: Dr. Samuel A Nigro M.D, Retired,
Assistant Clinical Professor Psychiatry, Case Western Reserve
University School of Medicine, 2517 Guilford Road, Cleveland
Heights, Ohio 44118, USA, Tel: 216 932-0575; Email:
sam@docnigro.com
Received: October 15, 2015 | Published: January 27, 2016

Atheists and secularists violate the above Ten Commandments day in and day out. Therefore, they are to be repudiated and rejected. They bring spiritless nihilism. They misuse science. They would deny you sacred music. They would deny St. Thomas Aquinas, St. Augustine, Beethoven, classical culture, logical thinking and all virtue. Atheists and secularists are not for the common good regardless of their rhetoric. They are for the common bad.

Atheists and secularists are pollution because they are out of touch with the planet both in terms of the animal kingdom, the environment and the noosphere (the layer of mind on the earth). Because of their stagnant, spiritless science, atheists and secularists claim there is no more ascending evolution. For secularists and atheists, man is it. What simplistic nonsense. Indeed, because of their nothingness, they have nothing on which to base their science either. Secularists and atheists can only rightly proclaim that there is nothing.

In contrast, the Church knows that man is not sufficient by himself. Intuitively, man knows there is more which he cannot well know nor fully understand ... just like frogs and other animals cannot fully grasp the higher nature of man. It is a natural phenomenon that earth creatures are not able to fully grasp that which is beyond them. As there are impulses to eat and care for one's self, there is an undeniable biological impulse to know, love and respect something greater than one's self, epitomized by God. Secularists and atheists believe in nothing, and therefore they have nothing and they should be ignored or helped to understand. 